anthropology \& materialism

\section{Anthropology \& Materialism}

A Journal of Social Research

Special Issue | I | 2017

Discontinuous Infinities

\title{
Where the Past Was, There History Shall Be
}

Benjamin, Marx, and the "Tradition of the Oppressed"

\section{Sami Khatib}

\section{(2) OpenEdition \\ Journals}

Electronic version

URL: http://journals.openedition.org/am/789

DOI: $10.4000 / a m .789$

ISSN: 2364-0480

Publisher:

CETCOPRA, CRASSH - Center for Research in the Arts Social Sciences and Humanities, Fakultät Gestaltung - Universität der Künste Berlin

\section{Electronic reference}

Sami Khatib, «Where the Past Was, There History Shall Be », Anthropology \& Materialism [Online], Special Issue | I | 2017, Online since 02 March 2017, connection on 19 April 2019. URL : http:// journals.openedition.org/am/789; DOI : 10.4000/am.789

This text was automatically generated on 19 April 2019.

Tous droits réservés 


\section{Where the Past Was, There History Shall Be}

Benjamin, Marx, and the "Tradition of the Oppressed"

\section{Sami Khatib}

"How to preserve the radical negativity of the revolutionary event? How to transmit the amnesiac rupture within history - to initiate a tradition of the impossibility of tradition? Our contemporary obsession with anti-monuments ... begins right here. Failing to keep pace with the events, revolutionary artifacts became instantly obsolete, thus needing to be destroyed, and the destruction in turn to be commemorated, sacralized, and eternalized, the ruins carefully preserved in their desecrated condition."

Rebecca Comay ${ }^{1}$

\section{Contra Tradition}

1 In his influential essay 'Socialism: Utopian and Scientific' from 1880, Engels deemed tradition "a great retarding force," "the vis inertiae of history." ${ }^{2}$ This negative view became the dominant version of historical materialism's take on tradition. Already in The Poverty of Philosophy (1847), Marx laid out the foundation of what later became the historical materialist concept of history:

After the triumph of the bourgeoisie there was no longer any question of the good or the bad side of feudalism. The bourgeoisie took possession of the productive forces it had developed under feudalism. All the old economic forms, the corresponding civil relations, the political system which was the official expression of the old civil society, were smashed. ${ }^{3}$

2 This assertion is not simply descriptive but politically emphatic and affirmative. Consequently, Marx acknowledged the revolutionary function of the bourgeois class: "As 
the main thing is not to be deprived of the fruits of civilisation, of the acquired productive forces, the traditional forms in which they were produced must be smashed." 4 As the 'fruits of civilisation' are only employed yet not exceeded by (or identical with) bourgeois society, the proletarian revolution could still be envisaged as the heir, however revolutionary, of these fruits. In this vein, in the Manifesto of the Communist Party (1847/48), Marx and Engels famously celebrated the task of the bourgeoisie as that of mercilessly liquefying the social relations of feudalism: "All that is solid melts into air, all that is holy is profaned". ${ }^{5}$ The proletariat and its revolutionary mission takes its cue from the revolutionary thrust of the dawn of the early bourgeois age, radicalising the disintegrating dynamic of capitalism, rooting out both the remainders of feudal society and the newly established socio-political forms of bourgeois society.

3 If tradition is the compliance with communal customs, passed on from an undefined past, tradition can only become an integral element of capitalist society once it is relegated to the limited fields of culture and religion. Although capitalism and its new ruling class, the bourgeoisie, "cannot exist without constantly revolutionising the instruments of production, and thereby the relations of production, and with them the whole relations of society," the compartmentalised domains of religion and culture allow for a conservative stance on 'tradition', which is, as it were, a bourgeois invention. Tradition as a bourgeois concept has its assigned place outside of the technological and social revolutions of the sphere of productive forces. That is to say, in the age of its bourgeois reproducibility, tradition is not per se 'conservative'; rather, it lends its 'retarding' (Engels) force to a project that is both affirmative and negative. While creating cultural meaning and legitimacy, it promises not to change current relations of production which are constantly under pressure from the transformative field of productive forces. Tradition allows for the fantasy that, in a world in which 'all that is solid melts into air', a limited district of bourgeois life could be exempted from radical change, and harmonised with the existing capitalist relations of production. Consequently, the political project of changing the relations of production, allowing for the collective access to property beyond private property, appears counter-traditional. As Marx and Engels succinctly put it: "The Communist revolution is the most radical rupture with traditional property relations; no wonder that its development involved the most radical rupture with traditional ideas." Nevertheless, as we shall see, it is precisely the history of class struggle and struggles against oppression that can become a source of emancipatory tradition. However, from a bourgeois 'conservative' perspective, the realm of tradition, traditional values and practices are defined as a reified, albeit limited zone of continuity capable of withstanding the revolutionising force of capitalist modernisation. Benjamin's later critique of the bourgeois concept of Kulturgüter, "cultural treasures" (SW 4, 391) and "cultural history" (SW 3, 268), will engage with this fantasy and its socialist variants. If cultural history's project is to "augment the weight of the treasure accumulating on the back of humanity," a revolutionary stance has to rely on modernity's destructive forces in order to gain "the strength to shake off this burden so as to take control of it" (ibid.). ${ }^{8}$

Marx and Engels' attack on tradition chimes with Benjamin's effort - one century later to refute the bourgeois idea of cultural history and its so-called 'cultural treasures'. ${ }^{9} \mathrm{~A}$ crucial difference, however, cannot be missed: Benjamin's concept of history does not rely on the idea that the dialectics of the ('retarding') relations of production, and the ('accelerating') productive forces would inevitably lead to social revolution. Marx's processual concept of historical materialism is not to be mistaken for economic 
automatism. However, his famous formulation from A Contribution to the Critique of Political Economy (1859) seems to locate the communist project of overcoming capitalism on the winning side of world history.

At a certain stage of development, the material productive forces of society come into conflict with the existing relations of production or - this merely expresses the same thing in legal terms - with the property relations within the framework of which they have operated hitherto. From forms of development of the productive forces these relations turn into their fetters. Then begins an era of social revolution. The changes in the economic foundation lead sooner or later to the transformation of the whole immense superstructure. In studying such transformations it is always necessary to distinguish between the material transformation of the economic conditions of production, which can be determined with the precision of natural science, and the legal, political, religious, artistic or philosophic - in short, ideological forms in which men become conscious of this conflict and fight it out. ${ }^{10}$

The outcome of this fight was not guaranteed in Marx's time either. When Benjamin wrote his last text, the theses "On the Concept of History" (1940) this fight was lost - at least for Benjamin and his generation.

\section{Dialectics of Tradition}

Instead of revoking his Marxism, Benjamin proposes a different reading of historical materialism, resulting in a radical revision of vulgar Marxism and, to a lesser degree, Marx's processual concept of history. From a non-defeatist position of defeat, Benjamin conceives of history not as a progressive flow of "homogeneous, empty time" (SW 4, 395), but as an anachronic constellation of past and present, shot through with sparks of messianic time. Benjamin calls these short-circuits of past and present Jetztzeit, "nowtime" (SW 4,395). According to this anti-evolutionary concept of history, the past is never simply gone; it can never be fully historicised unless it is recalled - cited in a revolutionary way. Only if politics has the capacity to anticipate the kairos, the 'opportune moment' for a "tiger's leap into the past," can "the dialectical leap" that "Marx understood as revolution" interrupt the catastrophic course of history (SW 4, 395). In this way, history, historiography, and revolutionary action are inextricably intertwined; an allegedly neutral perspective, detached from political struggles, only leads to "empathy with the victor"' (SW 4, 406). And "the rulers at any time," as Benjamin reminds us, "are the heirs of all those who have been victorious throughout history" (SW 4, 406). Against this form of victors' history, be it historicist, progressivist or evolutionist, Benjamin argues for a truly historical concept of history, aiming at the revolutionary encounter of past and present, accessible only for "the struggling, oppressed class" (SW 4, 394). In this sense, the task of the materialist historiographer is both radically partisan and universal: "The history-writing subject is, properly, that part of humanity whose solidarity embraces all the oppressed. It is the part which can take the greatest theoretical risks because, in practical terms, it has the least to lose" (SW 4, 404). ${ }^{11}$

7 The medium in which the present is connected to all lost causes and struggles of those who literally and metaphorically have lost their histories is called the 'tradition of the oppressed'. Against common views of historical materialism, Benjamin proposes a dialectical understanding of the notion of tradition in his preparatory notes for the theses 'On the Concept of History'. 
(Basic aporia: "Tradition as the discontinuum of the past in contradiction to history as the continuum of events." - "It may be that the continuum of tradition is semblance [Schein]. But then precisely the persistence of this semblance of persistence provides it with continuity.")

(Basic aporia: "The history of the oppressed is a discontinuum." - "The task of history is to get hold of the tradition of the oppressed.")

More on these aporias: "The continuum of history is the one of the oppressors. Whereas the idea [Vorstellung] of the continuum levels everything to the ground, the idea [Vorstellung] of the discontinuum is the foundation of real tradition."

[crossed out passage:]

What characterizes revolutionary classes at the moment of their action is the consciousness of historical discontinuity. On the other hand, however, the class's revolutionary action is most closely related to the class's concept (not only of coming history but also) of past history. This is only an apparent contradiction: bridging the gap of two millennia the French Revolution drew on the Roman Republic. (GS I, 1236) ${ }^{12}$

8 What Benjamin addresses here in terms of aporias relates back to the contradictory meaning of tradition. As the proverb has it, 'tradition is not to preserve the ashes but to pass on the flame.' Its root, the Latin verb tradere, conveys a variety of meanings, the most common of which is to hand down, to transmit, to pass on. However, tradere also denotes surrender, giving away, betrayal. This last meaning could give us a first hint of how Benjamin conceives of the 'tradition of the oppressed'. Tradition does not establish continuity through transmission but is a discontinuum fissured by lack, privation and betrayal. However, he claims that the fractured medium of the 'tradition of the oppressed' is not only negative, for history also transmits a redemptive messianic force. But how are we to detect this force, and who is 'we' in this case? In another note Benjamin writes:

The historical materialist who investigates the structure of history performs, in his way, a sort of spectrum analysis. Just as a physicist determines the presence of ultraviolet light in the solar spectrum, so the historical materialist determines the presence of a messianic force in history. Whoever wishes to know what the situation of a "redeemed humanity" [erlöste Menschheit] might actually be, what conditions are required for the development of such a situation, and when this development can be expected to occur, poses questions to which there are no answers. He might just as well seek to know the color of ultraviolet rays. (SW 4, 402)

Such messianic spectral analysis may bring an invisible colour to the fore. If the light of history also transmits messianic rays, then the medium in which they are imparted and discontinuously passed on is the 'tradition of the oppressed'. This medium is not continuous, transparent and neutral but discontinuous, opaque and politically partisan its texture is woven out of struggles, empty-spots and disjointed elements, which cannot be represented in one transmittable image or inscribed into one multifaceted yet coherent world-history. In this sense, the metaphor of continuous rays might be misleading; it does not come as a surprise that in the final version of the 'Theses' Benjamin limits his messianic imagery to "splinters of messianic time" (SW 4, 397). Moreover, with the messianic force in history, the boundaries of natural science's imagespace are reached. For Benjamin's historical materialist cannot count on scientific laws. Unlike a physicist, he or she has no measurement at hand to pursue a messianic spectral analysis of history. The only feature borrowed from natural science concerns its experimental character. Throughout the notes of the 'Theses', Benjamin acknowledges the tentative approach of his version of historical materialism. However, this experimental character has a politically firm guiding structure. For "[w]ithout some sort 
of assay [Prüfung] of the classless society, there is only a historical forgery [ Geschichtsklitterung] of the past" (SW 4, 407). ${ }^{13}$ Benjamin's experimental 'Theses' borrow their language and imagery from various fields of knowledge, be it Marxism, theology, surrealism, literary criticism or natural science. However, the fractured medium in which history will have been told is bound to a partisan experience and perspective. For only the 'tradition of the oppressed' imparts a genuinely historical image of the past. This is why Benjamin remains a fierce critic of the humanist idea of cultural heritage and commemoration; the latter always represents a reified image of the past, seen from the perspective of victor's of history, aiming at neutralising the messianic force in history.

In this sense, Benjamin's peculiar version of historical materialism is not limited to an alternative or 'messianic' historiography. Within the discontinuous medium of the 'tradition of the oppressed', struggles of the past are not diachronically strung together but synchronistically short-circuited. Therefore, past struggles cannot be narrated like a chronological story; they can only be cited in the present by conjuring fragments of history's "weak messianic power" - a Kraft, force "on which the past has a claim" (SW 4, 389). This conjuring or channelling, however, cannot intentionally be enforced. It is only by way of a messianic openness beyond the dichotomies of activity and passivity, intentional acting and non-intentional meditation, that a radically partisan and politically involved collective - the 'struggling, oppressed class' - can account for this weak messianic force by taking up what the latter addresses. There is no guarantee that the past's claim is taken up by its belated addressee.

\section{The Modality of Affective Time}

In the theses "On the Concept of History", Benjamin demonstrates how political action retroactively intervenes in the modality of each present's unfulfilled past. The site of this retroaction is class struggle.

Class struggle, which for a historian schooled in Marx is always in evidence, is a fight for the crude and material things without which no refined and spiritual things could exist. But these latter things, which are present in class struggle, are not present as a vision of spoils that fall to the victor. They are alive in this struggle as confidence, courage, humor, cunning, and fortitude, and have effects that reach far back into the past. (SW 4, 390)

12 In other words, through virtues like 'confidence, courage, humour, cunning, and fortitude' the current class struggle can modify its relation to the past. Besides being a struggle for the 'crude and material things', class struggle also imparts a medium through which lost struggles of the 'tradition of the oppressed' are present in current struggles. And vice versa the retroactive effect that the present has on the past corresponds to a claim that the past has on the present. These anachronic modifications of the relation of past and present cannot be registered objectively but can only be collectively channelled in the uneven course of class struggle. Referring to the Spartakusbund of Rosa Luxemburg and Karl Liebknecht, Benjamin affirms the collective affect of past failed revolutions in terms of "hatred" and the "spirit of sacrifice" "for both are nourished by the image of enslaved ancestors rather than by the ideal of liberated grandchildren" (SW 4, 394). In this sense, only "the struggling, oppressed class" is "the avenger that completes the task of liberation in the name of generations of the downtrodden" (SW 4, 395). These negative affects of the past, however powerless and defeated they may be, already had a 
transformative effect on their own past and still reverberate in our present. Their echoes are channelled through the affective medium of the 'tradition of the oppressed'. Rather than fetishising the image of failed struggles, as "left-wing melancholy" (SW 2.2, 425) would do, this partisan tradition actualises a weak potentiality of past failures in order to change the modality of the present. It is not that the present historicises and changes the past according its own demands but, on the contrary, the past puts the present into perspective, relativises and deconstructs the image of the present as the necessary outcome of history.

Benjamin's take on revenge is not surprising, given his reading of Marx. In a speech from 1856, Marx understood non-reciprocal revenge as a counter-factual affect and integral force of the historical-materialist concept of history.

I know the heroic struggles the English working class have gone through since the middle of the last century - struggles less glorious, because they are shrouded in obscurity, and burked by the middleclass historian. To revenge the misdeeds of the ruling class, there existed in the middle ages, in Germany, a secret tribunal, called the "Vehmgericht." If a red cross was seen marked on a house, people knew that its owner was doomed by the "Vehm." All the houses of Europe are now marked with the mysterious red cross. ${ }^{14}$

Such a secret tribunal has no formal or formalisable legal code, it does not comply with the rules of official world history - and neither does revolution which relies on hidden 'irregular' forces, elf- or kobold-like figures such as "Robin Goodfellow", "the old mole"15 who digs underground time-tunnels where the ruling classes' history denies revolutionary justice. Structurally similar, the act of revolution and the collective affect of revenge can bridge hundreds of years, short-circuiting disparate and seemingly unrelated events. Nothing could be further from later vulgar Marxist and social democratic beliefs in revolution as the quasi-automatic mechanism of progressive world history. The temporal form of extra-legal historical justice cannot be mapped from the perspective of the law and modern state violence: the former is uneven and contracted, the latter proceeds in "homogeneous, empty time" (SW 4, 395). It is in this sense that Marx's example of the medieval 'Vehmgericht' is not to be mistaken for a normative justification of non-normative acts. In advance, no universalisable guarantee can be given as to whether such acts are just or, as Benjamin's earlier essay "Critique of Violence" (1921) put it, manifest "divine violence" as the "crowd's divine judgment on a criminal" (SW 1, 252). Benjamin is thus careful not to not affirm all kinds of collective pathemata, passions, and affects. Rather, he demonstrates the difference of their images, modalities and temporalities.

The affective medium of past struggles imparts a non-linear temporality irreducible to the specific characteristics of its leaders or its historicisable events. In a radical sense, there is nothing to be learnt from past failures, no solace to be found, no instructive narrative to be told, no future utopia to be envisaged, no ideology to be distilled. Within the discontinuum of the 'tradition of the oppressed', the failed slave rebellion of ancient Spartacus, and the failed Spartacist uprising of 1919 have only one thing in common: their attempt to interrupt the course of oppressive history. The fractured medium that connects and separates these disparate struggles only transmits its own mediacy - not in order to museumise past failures, but to set them free - as history. Put differently, if the historical materialist's task of "blast[ing] open the continuum of history" (SW 4, 396) only comes into perspective from within class struggle, then the disruptive "fight for the crude and material things" (SW 4, 390) is the affective medium that enables a properly 
historical perspective on the past (in contradistinction from historicist or historicalmetaphysical concepts of history). But how can the past be changed in this medium?

Slavoj Žižek rightly points out that Benjamin's anti-historicist stance relies on a "revolutionary Act that will [...] retroactively realize the crushed longings of all past, failed revolutionary attempts." ${ }^{16}$ Put differently, only a revolutionary act within class struggle can fully actualise and realise a past that has not yet existed. From a historical perspective, the past is still 'ahead' of us.

What this means is that, in a properly historical perspective as opposed to evolutionist historicism, the past is not simply past, but bears within it its proper utopian promise of a future Redemption: in order to understand a past epoch properly, it is not sufficient to take into account the historical conditions out of which it grew - one has also to take into account the utopian hopes of a Future that were betrayed and crushed by it - that which was 'negated', that which did not happen - so that the past historical reality was the way it was. ${ }^{17}$

Understood in this way, messianic redemption is not about some apocalyptic intrusion from 'outside' (a divine intervention into human affairs) but about the restoring (or, in more theological terms, 'restitutio in integrum' or 'tikkun') of the past's repressed potentialities. This restoration is not conservative but opening: it ex-poses the present as changeable. The task is not to rewrite history from the perspective of the present, but to destabilise the seemingly solid ground of the present as historical outcome of the past.

To put it in even clearer terms: when we say the present redeems the past itself, that the past itself contained signs which pointed towards the present, we are not making a historicist-relativist statement about how there is no 'objective' history; how we always interpret the past from our present horizon of understanding; how, in defining past epochs, we always - consciously or not - imply our present point of view. What we are claiming [of Benjamin, S.K.] is something more radical: what the proper historical stance (as opposed to historicism) 'relativizes' is not the past (always distorted by our present point of view) but, paradoxically, the present itselfour present can be conceived only as the outcome (not only of what happened in the past, but also) of the crushed potentials for the future that were contained in the past. ${ }^{18}$

Žižek's reading captures the radical kernel of Benjamin's 'Theses'. The latter's inherently 'theological' or 'messianic' dimension does not contradict or compromise its Marxist impulse. Rather, the displaced language of theology functions here as a corrective of scientific Marxism to flesh out the revolutionary core of a genuinely historical-materialist concept of history vis-à-vis historicist, evolutionist or metaphysical philosophies of history, which either eternalise or de-historicise the past. The past is never 'just out there' - it is not a given, a fait accompli, since it is never ontologically fully constituted. Without its hidden, repressed, or crushed potentialities, the past never arrives at the point where it can become history in its full sense.

But how can the present and its current political struggles redeem the past and make it history? An 'act' is never a transparent, consciously and voluntarily performed action that can be appropriated by a certain subject. Rather, "in an authentic act, the highest freedom coincides with the utmost passivity, with a reduction to a lifeless automaton who blindly performs its gestures." ${ }^{19}$ The act of retroactively changing the present's relation to the past is such an act in which radical activity (class struggle) and utmost passivity (the weak messianic force) coincide. Paradoxically, the gestures of such passive-active acts are performed by subjects who cannot fully own or totalise their 'own' acts. The gestures that redeem the past are not at the disposal of some self-identical subject of history. 
Benjamin's key term to theorise the gestures of such active-passive acts is 'citation': the texture of a particular past is cited/redeemed by a particular present. However, there is no author of history to sign the citation. We will later return to this point in the context of Benjamin's reading of Marx.

For the moment let us concentrate on how Benjamin's 'Theses' interweave the messianic citability of the past with its narratibility and transmittability. In the third thesis he writes:

The chronicler who narrates events without distinguishing between major and minor ones acts in accord with the following truth: nothing that has ever happened should be regarded as lost to history. Of course only a redeemed mankind is granted the fullness of its past-which is to say, only for a redeemed mankind has its past become citable in all its moments. Each moment it has lived becomes a citation a l'ordre du jour. And that day is Judgment Day. (SW 4, 390)

The messianic (universal and integral) citability of the past will have become possible only for a 'redeemed mankind'. The future past of messianic citability, however, already changes the modality of citing the past in the unredeemed present. If 'nothing that has ever happened should be regarded as lost to history', as Benjamin sums up the task of the pre-modern chronicler, then the modern historian too cannot simply dispose of his or her past and treat it as completed. The past is incomplete, for only the present holds the key to complete (that is, to redeem) the past by citing it. For an unredeemed mankind this citation is not possible at any time but only at a very particular moment when the "true image of the past flits by" (SW 4, 390). In other words, an unredeemed mankind can miss the "secret agreement between past generations and the present one" (SW 4, 390), and lose its ability to quote the past in a redemptive way. The citability of the past is not subject to the voluntary demands and interests of the present. Rather, the secret agreement - the sympathy and synchronicity - of a particular present and a particular fragment of the past only happens in a zone of indistinction between activity and passivity, cognition and affection, collective dreaming and awaking, conscious and "notyet-conscious knowledge of what has been" (AP, N 1,9). We will later see how Benjamin can theorise this peculiar short-circuit of (re)cognisability and redeemability, epistomology and ontology.

For the moment, let us follow the intertwinement of collective affects and the past's redeemability. Werner Hamacher is right when he argues that Benjamin's 'Theses' uncover "the temporal structure of the political affect." ${ }^{20}$ The two types of political affect, the negative avenging and the positive encouraging one, have temporal effects connecting political struggles of the past and the present. The retroactive effects of present struggles and the after-history of past struggles intersect in what Benjamin calls 'weak messianic power (Kraft)' - a counter-hegemonic undercurrent within the layers of dominant history, experienced only by those who recognise themselves as intended by it. This recognition, however, is not timeless-contemplative but temporal-affective; its discontinuous medium is connected to the 'tradition of the oppressed'. The individual entry point to this collective medium, which could channel and register the 'weak messianic power' of the past, is to be found in moments of happiness. As Benjamin writes in the second thesis: "the image of happiness we cherish is thoroughly colored by the time to which the course of our own existence has assigned us" (SW 4, 389). The modality of how past and present relate to each other is not objective or factual but experienced and hence changed in an affective way, channelled through affective time. Cognition and 
affect, potentiality and actuality, historical time and political struggle intersect here in a peculiar way. As Hamacher comments:

The thesis demonstrates that cognitive acts, determined by the micro-structure of the affective time, are political operations. The cognition at stake here, however, is the cognition of happiness. Happiness never is experienced in a present without this present relating to that which has been (Gewesenes). It is not, however, experienced on a past reality, but on the irrealis of its non-actualised possibility. ${ }^{21}$

The affective time of missed possibilities of the past cannot be mapped by a teleological understanding of the relation of actus and potentia. Happiness is not a goal - it is not grounded in the stable presence of an individual affect (the classic liberal 'pursuit of happiness'), but presents the lucky embodiment of affective time. Benjamin's German word for happiness, Glück, denotes both the conjuncture of happiness and the disjuncture of luck. Luck or fortune is not simply contingency, the lucky conjoining of disparate 'touches', but the happy interruption of what has been violently conjoined. It is the ateleological opening for new conjunctures. And indeed, as Jonathan Lear comments on Aristotle and Freud, happiness is "not the ultimate goal of our teleologically organized strivings, but the ultimate ateleological moment: a chance event going well for us - quite literally, a lucky break."22 It is in this profane and a-teleological sense that we should understand Benjamin's idea of happiness: as a disruptive break (re)opening "possibilities for new possibilities" 23 that were foreclosed in the past. As Hamacher reminds us, the German noun for redemption, Er-lösung, also connotes Lösung [release], which is part of the German word for the strictly prosaic meaning of redemption: Ein-lösung, "a redeeming [...] of possibilities, which are opened with every life and are missed in every life." ${ }^{24}$ This profane reading of messianic redemption as lucky break and modal change does not only lay bare the temporal structure of the political affect: it also alludes to the split between history and the past. Put differently, what affective time "bridges" or "mediates" is nothing other than this gap between an unhistoricisable past and history as ontologically incomplete.

\section{From Repression to Repetition}

In 1954 Jacques Lacan wrote: "History is not the past. History is the past in so far as it is historicised in the present - historicised in the present because it was lived in the past." 25 This categorical distinction between past (le passé, Vergangenheit) and history (l'histoire, Geschichte) is also at stake in Marx's famous article on the Eighteenth Brumaire of Louis Bonaparte from 1852.

Men make their own history, but they do not make it as they please; they do not make it under self-selected circumstances, but under circumstances existing already, given and transmitted from the past. The tradition of all dead generations weighs like a nightmare on the brains of the living. ${ }^{26}$

The psychoanalytical name of this nightmare might be trauma. In a historicalpsychoanalytical sense, the past is not simply gone or dead but undead - and that is why it haunts the present like an Alp, as Marx writes in the German version. An Alp is an elf, a figure from Germanic mythology that was believed to cause nightmares, Alpträume (literally: elf-dreams), by sitting on the chest of the sleeping person. If we transpose this image to the scene of collective history and read it with Benjamin, we might add that the 'tradition of all dead generations' will keep on haunting the present like a nightmare, an Alptraum, as long as its dead mode of transmittability represses the tradition of the 
oppressed'. Even if the experiences of all oppressed traditions are erased and flattened into the linear representation of 'victor's history', history's repressed will return in a displaced scene, in distorted shape - as specters.

Benjamin, however, does not affirm this kind of spectrality. In contrast to more recent accounts - one might think of Derrida's Specters of $\mathrm{Marx}^{27}$ - he calls for a revolutionarymessianic cessation of the past's undeadness. However, if modernity cannot bury its dead, then the 'book of history' can never be closed - unless the claims of the 'tradition of the oppressed' are settled and the past is historicised in the present. Following Hegel and the young Marx, the precondition for a real burial is a reconciled separation from the past and its undead specters. For only a "reconciled humanity will take leave of its past - and one form of reconciliation is cheerfulness", as Benjamin paraphrases Marx in the Arcades Project (AP, N 5a,2) ${ }^{28}$ In order to "take leave of its past cheerfully," (AP, N 5a,2) ${ }^{29}$ humanity has to repeat the past in a comical way. In the same passage from his Contribution to the Critique of Hegel's Philosophy of Right (1843), Marx writes: "History is thorough, and passes through many stages when she carries a worn-out form to burial. The last stage of a world-historical form is its comedy. The gods of Greece, who had already been mortally wounded in the Prometheus Bound of Aeschylus, had to die yet again - this time a comic death - in the dialogues of Lucian. ${ }^{30}$ Whereas Marx's earlier text from 1843 still draws on a Hegelian sequence of original tragedy and comical repetition, the later text on the Brumaire from 1852, reflecting on the failed revolution of 1848, adds a non-cheerful form of farcical repetition. In this vein, Marx famously declared:

The social revolution of the nineteenth century cannot draw its poetry from the past, but only from the future. It cannot begin with itself before it has stripped off all superstition in regard to the past. Earlier revolutions required recollections of past world history in order to drug themselves concerning their own content. In order to arrive at its own content, the revolution of the nineteenth century must let the dead bury their dead. ${ }^{31}$

However, as I will argue, the revolutionary task of burying the dead - while realising the real content of revolution - is also a form of repetition - a non-farcical repetition that recalls the past's undeadness in order to let it go. This form of repetition is not about conjuring up a specter, the repetition of a certain content or the reenactment of past happenings, but repeats its own attempt to work through the past in order to take leave of it cheerfully. As we will see, what the younger Marx associated with comical cheerfulness, Heiterkeit, the later Marx calls proletarian revolution. It comes as no surprise that Benjamin too is well aware of the coupling of comical repetition and revolution. In a note written for his famous essay on "The Work of Art In the Age of Mechanical Reproduction" (1935/36), he proposes to counter the beastly severity of fascism with the cheerfulness, "Heiterkeit," of communism (GS I, 1045). Revolutionary cheerfulness is not about specific affects of the political but about a retroactive intervention in the causal chain of historical events that lead to the farcical repetitions in the present. In other words, revolutionary repetition is cheerful only insofar as it breaks with the compulsion to repeat. As we will later see, this sort of cheerful repetition of history lays bare the temporal structure of the political affect that Hamacher detected in Benjamin's theses "On the Concept of History".

With regard to Benjamin, it is the 'tradition of the oppressed' that presses for a repetition of a repressed (and in this sense undead) past in order to take leave of it. The comical dimension of this repetition, however, is not simply uplifting or entertaining. If repetition is "constitutive of the comic genre as such," ${ }^{2}$ as Alenka Zupančič notes, we 
have to distinguish between two different forms of repetition. Relying on Marx's Brumaire, Zupančič mentions repetition as farce and repetition as proletarian revolution. And indeed, Marx begins his argument with the famous dictum: "Hegel remarks somewhere that all facts and personages of great importance in world history occur, as it were, twice. He forgot to add: the first time as tragedy, the second as farce." ${ }^{33}$ The farcical form of repetition is the formula of the failed revolution from 1848 whose revolutionary imagination came up with "nothing better to do than to parody, now 1789." ${ }^{44}$ However, Marx does not categorically reject any form of quoting from the past. He mentions "epochs of revolutionary crisis" when its protagonists "anxiously conjure up the spirits of the past to their service and borrow from them names, battle cries and costumes in order to present the new scene of world history in this time-honoured disguise and this borrowed language." ${ }^{35}$ It is worth noting that the lack of tragic authenticity is not Marx's concern. He concedes that "the awakening of the dead in those revolutions served the purpose of glorifying the new struggles, not of parodying the old; of magnifying the given task in imagination, not of fleeing from its solution in reality; of finding once more the spirit of revolution, not of making its ghost walk about again." ${ }^{36}$

Benjamin, who read Marx's Brumaire in the summer of 1938, ${ }^{37}$ radicalised this insight when formulating his famous $14^{\text {th }}$ thesis "On the Concept of History" in 1940:

History is the subject matter [Gegenstand] of a construction whose site is not homogeneous, empty time, but time filled full by now-time [Jetztzeit]. Thus, to Robespierre ancient Rome was a past charged with now-time, a past which he blasted out of the continuum of history. The French Revolution viewed itself as Rome reincarnate. It cited ancient Rome exactly the way fashion cites a bygone mode of dress. Fashion has a nose for the topical [Aktuelle], no matter where it stirs in the thickets of long ago; it is the tiger's leap into the past. Such a leap, however, takes place in an arena where the ruling class gives the commands. The same leap in the open air of history is the dialectical leap Marx understood as revolution. (SW 4, 395)

Indeed, Benjamin's concept of now-time, Jetztzeit, is not so far from Marx. The revolutionary citation of the past in the present is not to be mistaken for inauthentic imitations of past revolutions ('parody' or 'farce'). Moreover, within the disruptive temporality of Jetztzeit the very distinction between historical authenticity and inauthenticity loses its linear evidence: what is copy, what is original - and what comes first? A citation, as Benjamin comments on Brecht, is never a mere repetition of a text; on the contrary, the quoted text interrupts the continuity of the present one and thereby discovers something new: a new insight, situation, context, or task. ${ }^{38}$ The citability of Brechtian gestures and, more generally, textual fragments also applies to the texture of history. "If one looks upon history as a text" (SW 4, 405) - a text that only future readers are capable of fully deciphering - it is only the particular citability of a certain fragment of the past at a certain moment that enables the legibility and recognisablity of historical textures. The true image of the Roman Republic flitted by in the moment of its revolutionary citation in the French Revolution of 1789 - the moment when the true image of the Roman Republic "attain[ed] to legibility" (AP, N 3,1). Moreover, following Benjamin's historical-materialist hermeneutics of historical texts, we can state that the true image of a past happening only reveals itself as a proper historical event with a certain delay - after it will have been repeated ('cited') in a non-farcical way. The paradox, however, is that this historical repetition performs a kind of original repetition - 'history' only repeats itself at one certain moment in time (what Benjamin's Arcades Project calls "now of recognizability"). In other words, we have to distinguish between a particular 
historical repetition and universal messianic repeatability in a manner that recalls what we noted earlier about messianic citability in the third thesis "On the Concept of History". Against conventional logics, here we are not to abstract from particular historical repetitions in order to arrive at universal repeatability. And indeed, as Benjamin states in the Arcades Project, the historical-materialist task is "to break with vulgar historical naturalism" and "to discover in the analysis of the small individual moment the crystal of the total event [Totalgeschehens]" (AP, N 2,6). In order to grasp Benjamin's counterintuitive move fully, we have to presuppose the existence (however weak) of the total event. Although the messianic totality of all events is logically prior to the aforementioned congealed crystal, nothing can be deduced from the former. And vice versa, totality is a category that can never be deduced from empirical reality or metaphysical abstractions. The retroactive logic of messianic redemption can be summed up as follows: the universal messianic repeatability of the past is the structural condition of any particular historical repetition. It is in this sense that Benjamin's concepts of Jetztzeit and citability bear witness to the possibility of non-farcical modes of repetition. These notions, however, only gain their full argumentative thrust when we read them vis-à-vis the Marxian text. Instead of limiting its critique to the farcical embodiment of the specter of past revolutions, Marx's Brumaire provides us with a theory of how the realm of history is entered into through non-farcical repetition - by unevenly working through past failures.

\section{History as Tragedy, Comedy and Farce}

31 In Marx's Brumaire, revolutionary repetition is the mode in which the proletarian revolution works through, and gets rids of the specters of the past. This working through is uneven, discontinuous, and repetitive. In contrast to bourgeois revolutions,

proletarian revolutions [...] criticize themselves constantly, interrupt themselves continually in their own course, come back to the apparently accomplished in order to begin it afresh, deride with unmerciful thoroughness the inadequacies, weaknesses and paltrinesses of their first attempts, seem to throw down their adversary only in order that he may draw new strength from the earth and rise again, more gigantic, before them, recoil ever and anon from the indefinite prodigiousness of their own aims, until a situation has been created which makes all turning back impossible, and the conditions themselves cry out:

Hic Rhodus, hic salta!

Here is the rose, here dance $!^{39}$

Instead of reading this final exclamation in a teleological way, we cannot miss Marx's emphasis on the repetitive structure of this kind of revolutionary working through of the past. The revolutionary leap, saltus, cannot count on historical-metaphysical guarantees. Rather than arriving at a final more perfect state like in social-democratic fantasies of socialism, the formula of the proletarian revolution seems much closer to Samuel Beckett: Ever failed. No matter. Try Again. Fail again. Fail better. The modal leap from failing once to failing better retroactively changes the parameters of the possible of preceding attempts. Repetition here is both stubbornly insisting and retroactively changing. As Zupančič argues:

It is not an "empty repetition" as revolution in the service of perpetuating the given, but a stubborn attempt to do something against all odds, which, because of its repetitious character, leaves the realm of the heroic and enters a territory closer to the comic - not because it keeps failing, but because it keeps insisting. ${ }^{40}$ 
In order to actualise lost potentialities of failed revolutions of the past, we are to repeat history in this stubbornly insisting manner. Hence, a new failure is never a mere repetition of a past failure. By virtue of perpetual insistence the act of 'failing again' changes something in the very nature of trying. It all comes down to how we understand the 'again' in failing: if every new trying in the present draws on the present (im)perfect of 'having failed', every coming failure actualises the revolutionary impulse of its original failure and gives it a different twist. Moreover, it is only the act of 'failing again' that can lay bare the non-actualised potentialities of past failures. Here, the planes of epistemology (our historiographic image of the past as historia rerum gestarum) and ontology (the impossible real object of historiography as res gestae) intersect and allow for a concept of history that bypasses the conventional alternative of either pluralism of historical narratives or univocity of one hegemonic History with a capital H. Instead of compulsively repeating the past, the realm of transformative repetition is entered as soon as the comical repetition of the past gets hold of the true image of the past's original tragedy. Seizing this true image does not mean to recognise the past 'the way it really was'. Rather, "articulating the past historically," as Benjamin reminds us, "means appropriating a memory as it flashes up in a moment of danger" (SW 4, 391). Setting aside what the subject matter of such memory could be, ${ }^{41}$ let me rephrase Benjamin's insight with regard to Marx. Seizing the true image of the past as it "flashes up at the moment of its recognizability" (SW 4, 390) is nothing else than repeating the past in its full potentiality and actualising the scope of its failures and defeats in the here and now. In other words, the act of 'failing again' and the act of 'seizing the true image of the past future' are actually the same act of transformative repetition, yet seen from different perspectives. What from an epistemological viewpoint reveals itself as a truth about the past, realises itself in the actual present by changing the ontology of what has been, and the modality of what shall be. The impossible object of the past is never simply gone - it will have been recognised by a present yet to come. It is history's peculiar temporality of future past, or futur antérieur, that provides the shifting ground of every new act of trying and failing. The "logical time" (SW 1,276) of grasping the true image of what will have been intervenes in the modality of the present by changing the horizon of the possible. ${ }^{42}$

However, the logic of transformative repetition is uneven and disruptive. Despite its stubborn insistence, the act of 'trying again' carries no guarantee of failing better. The political danger of missing the true image of the past as it 'flits by' may lead to a change from bad to worse. As we noted earlier with Zupančič: in the case of political struggle and revolution as repetition, the comical cheerful aspect is reduced to its structural dimension of insistence. Moreover, with Benjamin we might add: the retroactive logic of transformative repetition can be transmitted only by the 'tradition of the oppressed'. It is in this analytical-materialist sense that we may read the motto that Benjamin's friend Ernst Bloch attributed to Thomas Münzer and the German Peasants' War: Geschlagen ziehen wir nach Haus, unsere Enkel fechten's besser aus. ('Beaten we are heading home, but our heirs in battle will fight on'.) ${ }^{43}$ The stubborn insistence on fighting-on does not simply repeat the failures of past battles: it even fails at repeating the failures of the past. Calling on its heirs in battle, the discontinuous tradition of Thomas Münzer and his beaten peasant army transmits "the image of enslaved ancestors rather than [...] the ideal of liberated grandchildren" (SW 4, 394). However, even this image of defeat is unstable - it fails to be passed on as heritage, be it cheerful or vengeful. The medium of the "tradition of the oppressed' only transmits its own broken mediacy, rendering it impossible to 
commemorate it in a linear conventional way. Regarding the Peasants' War and the attempt to establish an artificial counter-tradition in writings such as Wilhelm Zimmermann's History of the Peasants' War, Benjamin succinctly notes: "this was not successful" (GS I, 1236). In more recent history, in the aftermath of the failed Spartacist Uprising of 1919, Weimar Germany's Communist Party (KPD) faced precisely this paradox: how to commemorate a failure without fetishising the image of defeat?

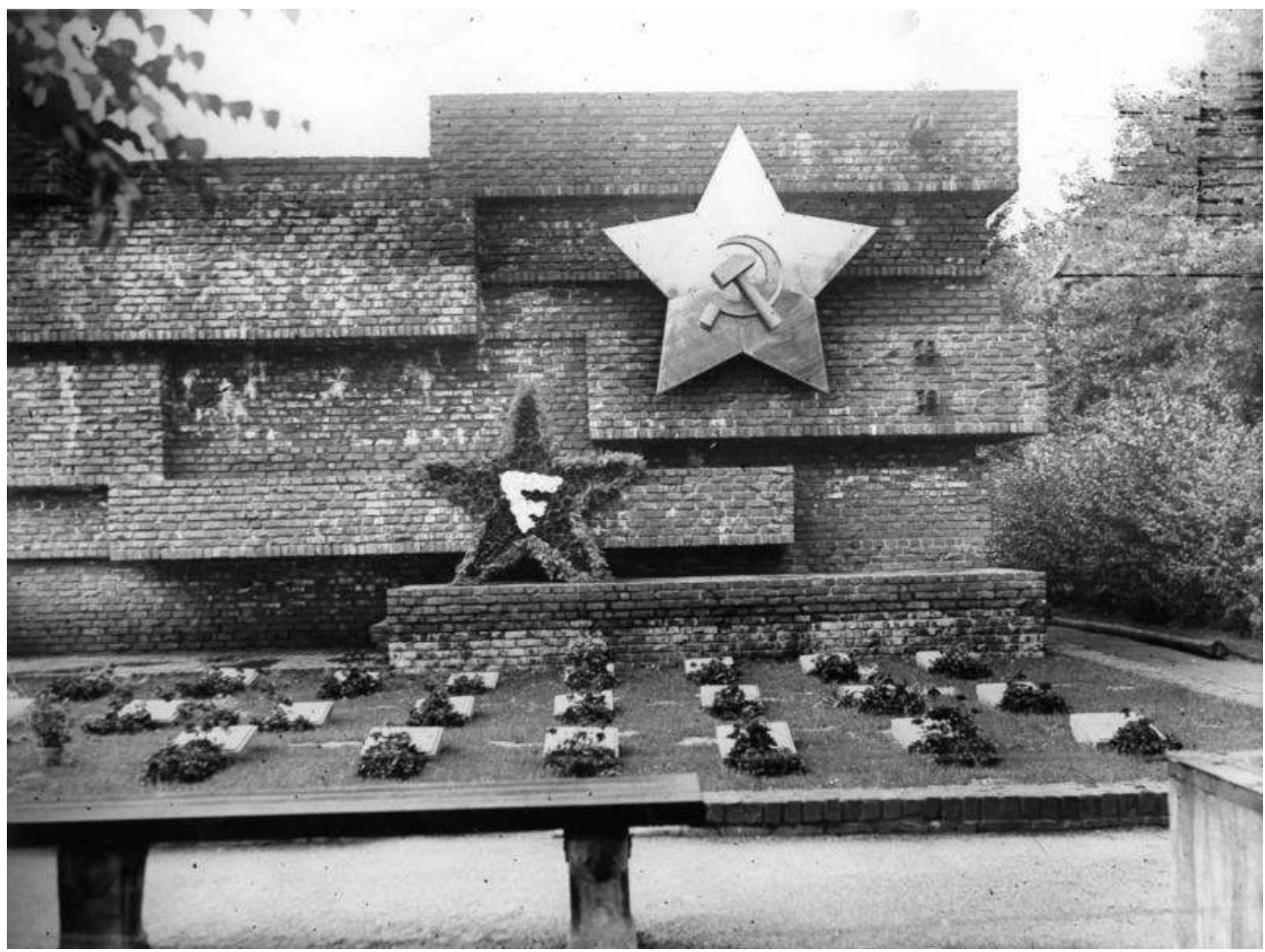

Revolutionsdenkmal or "Monument to the November Revolution," Berlin, built in 1926, demolished in 1935, designed by Ludwig Mies van der Rohe, commissioned for the KPD by Eduard Fuchs (Creative Commons license: Bundesarchiv, Bild 183-H29710 / CC-BY-SA 3.0).

\section{Where the Past Was, There History Shall Be}

Benjamin's reference to the failed Spartacus uprising, led by Rosa Luxemburg and Karl Liebknecht, is itself written from a position of defeat. Insisting on the working class's "hatred and its spirit of sacrifice" (SW 4, 394), thesis XII calls for political vengeance beyond the scope of symmetrical retribution. The revolutionary "image [Bild] of enslaved ancestors" (ibid.) is turned against the social democratic "ideal of liberated grandchildren" (ibid.). Such an image, Bild, presents only its political mediacy; it does not illustrate or represent anything beyond its presentation. It is itself an image of class struggle as "a fight for the crude and material things" (SW 4, 390). But how can such an raw, unrefined image be framed, represented, memorialised?

After having initially favoured a more traditional proposal to erect a memorial for the murdered revolutionaries of 1918/19, the German Communist Party (KPD) commissioned the key member and later director of the Bauhaus, Ludwig Mies van der Rohe, with the construction of a Revolutionsdenkmal at Berlin's Friedrichsfelde cemetery, where Liebknecht and Luxemburg were buried. Without going into details of Mies van der Rohe's daringly abstract proposal, its realisation, inauguration and subsequent 
demolition by the Nazi government in $1935,{ }^{44}$ it is worth noting that Mies van der Rohe's original plan for the Monument to the November Revolution from 1926 bore the inscription Ich bin, Ich war, Ich werde sein (I am, I was, I shall be) ${ }^{45}$ - a motto taken from Rosa Luxemburg's last article, "Die Ordnung herrscht in Berlin" ("Order Rules in Berlin") published on January 14, 1919. Luxemburg, in turn, got this formulation from Ferdinand Freiligrath's poem "Die Revolution" ${ }^{46}$ written in 1851 in the aftermath of the failed 1848 revolution. Her article concludes with the following passage:

"Order prevails in Berlin!" You foolish lackeys! Your "order" is built on sand.

Tomorrow the revolution will "rise up again, clashing its weapons," and to your

horror it will proclaim with trumpets blazing: I was, I am, I shall be! ${ }^{47}$

This series of historical citations, repetitive invocations of failed revolutions, does not declare final defeat or victory but insists on the temporal loop that the formula 'I was, I am, I shall be!' introduces. What sounds like the linear succession of past, present, and future, is fissured by both the insistence of the 'tradition of the oppressed', and the traumatic pressure of history's repressed. Besides its peculiar temporality, the threefold repetition of the pronoun ich, I, poses the question of who is speaking here. It is revolution itself that declares its structurally comical insistence. Moreover, Luxemburg's prosopopoeia is the only way to make the revolution 'speak', since there is no preexisting speaker that could say 'I, the revolution'. As we said before, the revolutionary/analytic act of restoring the past's crushed potentialities cannot be appropriated by a sovereign subject of history, since the ich, 'ego', of the enunciation 'I was, I am, I shall be' is still caught in the spectral net of es, 'id' - the trauma of the past. Working through the unconscious non-symbolisable trauma of the past is a constructive and destructive act that cannot rely on already established subjects. The revolutionary ego of 'I was' - the collective subject of historical enunciation - has still to be constructed in order to allow for the modality of 'I shall be'. In this sense, Luxemburg's formula subverts any attempt to psychologise and individualise her revolutionary prosopopeia by attaching its unownable gesture to the clichéd image of a pure martyr who heroically sacrificed her life in a 'pure' act.

With regard to Freud and Luxemburg, the task of Benjamin's historical materialist is thus to work through the collective unconscious of the present and transform it into the actuality of the collective ego of revolutionary politics. As is well known, Freud summarised the task of psychoanalysis according to this formula: "Where id was, there ego shall be. It is a work of culture". ${ }^{48}$ With Benjamin and Marx we might add: where the crushed potentialities of the past were, there the history of the struggling, oppressed class shall be. It is a work of historical politics, Geschichtspolitik. If the non-linear medium of this work is the 'tradition of the oppressed', then we cannot fail to read the proper tense of Luxemburg's wager Ich war, ich bin, ich werde sein as Wo Es war, werde Ich gewesen sein. The futur antérieur of 'where id was, there ego will have been' lays bare the temporal structure of the political affect that Benjamin discovered in his 'Theses'. In this sense, we may also reread Marx's call to let the dead bury the dead. The constructive work of replacing 'id' by 'ego' will have been completed in the moment when the struggling and oppressed class cheerfully destroys its ties to the past and historicises its specters as history. This moment, however, is not an empirical date in the future but lies hidden in the act of repeating the past in the present by changing their modal relation.

With these remarks we can understand how the epistemological task of seizing the past's true image relates to the ontological incompleteness of history. Only by grasping this 
temporal loop, by constructively working through the specters of the past, can we bury history's undead. This burial, however destructive it may be, does not serve the commemoration of dead generations but aims at changing the present in the moment of recognising the true image in the past - an image that suddenly, seemingly from nowhere, 'speaks' to the current oppressed in a situation of danger. Only this act of cognition, channelled through the political affect of the 'tradition of the oppressed', produces an authentically historical image (in contrast to historicism). Such a cognising act intervenes in the ontology of what has been and might even betray the memory of past generations of the downtrodden. After all, as we have seen, the Latin verb tradere (to pass on, hand over) also connotes surrender and betrayal. In this sense, Benjamin's historical materialist concept of history does not serve the demands of history's dead but articulates on a more fundamental level the past's undeadness and turns its specters against each other. What is constructed in such a political/analytic act bears witness to a profane striving for 'messianic' redemption - a redemption that completes, fulfils, and repeats a past that has never happened in the first place. However, to take leave of one's past cheerfully does not mean to aim at a happy end of history, a Hegelian Erinnerung, remembering and internalising of all of the spirits of the past. ${ }^{49}$ Rather, it means to admit oneself to the danger of failure and failing again - not in order to fetishise the memory of defeat but to change the parameters of the possible and to leave the realm of compulsively repeating the past. In other words, only this modal change, while failing at repeating the content of past failures, enters the realm of a transformative, revolutionary repetition of history. This structure of transformative repetition also applies to Benjamin's text. Repeating Benjamin today does not mean to repeat his criticism of vulgar Marxism once more in order to defeat an opponent that has long been defeated by the real history of capitalism. Such a repetition would truly be farcical. Rather, repeating Benjamin aims at taking leave of his past cheerfully by working through the undead specters of our past. Instead of assimilating Benjamin to our times and reading our present into Benjamin's own historical present, our task is rather to read a Benjaminian text that was never written in the first place. Here, our historical distance to Benjamin's time appears as a connection through disconnection. It is only this truly historical discontinuity that we 'share' with Benjamin and the 'tradition of the oppressed'. Contrary to today's culture industry of commemoration and its customized production of memory without history, Benjamin's concept of the 'tradition of the oppressed' recalls the battleground of history as a site of repressed possibilities of the present. For only the present can do justice to the oppressed claims of history's repressed. Such an act of justice, however, does not serve the demands of (un)official politics of commemoration and does not aim at the production of a 'balanced' representation of the past. Benjamin's Geschichtspolitik does justice to the past by repeating history as a comical sequence of failed attempts to break with history's compulsion to repeat. This sort of uneven double negation, however, remains negative: ${ }^{50}$ it even fails at producing the image of a proper failure: "'no glory for the victor, no sympathy for the defeated"' (GS I, 1237). ${ }^{51}$ 


\section{BIBLIOGRAPHY}

AP: BENJAMIN, Walter, The Arcades Project, trans. Howard Eiland, Kevin McLaughlin (Cambridge, MA: Belknap Press of Harvard University Press, 1999).

GS: BENJAMIN, Walter, Gesammelte Schriften, eds. Hermann Schweppenhäuser \& Rolf Tiedemann, 7 vols. (Frankfurt/Main: Suhrkamp, 1972ff.).

SW: BENJAMIN, Walter, Selected Writings, eds. Marcus Bullock \& Michael W. Jennings, 4 vols. (Cambridge, MA: Belknap Press of Harvard Univ. Press, 1996ff.).

$* * *$

COMAY, Rebecca, Mourning Sickness: Hegel and the French Revolution (Stanford: Stanford University Press, 2011).

DERRIDA, Jacques, Specters of Marx: The State of the Debt, the Work of Mourning and the New International, trans. Peggy Kamuf (London/New York: Routledge, 1994).

FREILIGRATH, Ferdinand, "Die Revolution”, in: Neuere politische und soziale Gedichte, 1849-51, stable URL: http://gutenberg.spiegel.de/buch/ferdinand-freiligrath-gedichte-5009/30.

FREUD, Sigmund, Gesammelte Werke, vol. 15 (London: Imago, 1940; Frankfurt/Main: Fischer, 1961).

HAMACHER, Werner, “'Now': Walter Benjamin on Historical Time”, in: Walter Benjamin and History , ed. Andrew Benjamin (London, New York: Continuum, 2005).

HEGEL, Georg Wilhelm Friedrich, "Phänomenologie des Geistes”, in: Werke, vol. 3, eds. Eva Moldenhauer \& Karl Markus Michel (Frankfurt/ Main: Suhrkamp, 1986).

KHATIB, Sami, “Politics of 'Pure Means': Walter Benjamin on Divine Violence”, in: Black Box: A Record of the Catastrophe, vol. 1 (Dec 2015), pp. 87-103.

KHATIB, Sami, "Walter Benjamin and the Subject of Historical Cognition," in: "Walter Benjamin Unbound", Special Issue of Annals of Scholarship, eds. Alexander Gelley, Ilka Kressner \& Michael G. Levine, vol. 21.1 (2015), pp. 23-42.

KHATIB, Sami, “A Non-Nullified Nothingness: Walter Benjamin and the Messianic," in: Stasis. Journal in Social and Political Theory, "Politics of Negativity", No. 1 (Fall 2013) pp. 82-108, stable URL: http://stasisjournal.net/images/khatib1_eng.pdf.

KHATIB, Sami, “The Messianic Without Messianism. Walter Benjamin's Materialist Theology," in: Anthropology \& Materialism. A Journal of Social Research, “Across the Fields”, No. 1 (2013), stable URL: http://am.revues.org/159.

LACAN, Jacques, The Seminar of Jacques Lacan, Book 1: Freud's Papers on Technique 1953-1954, ed. Jacques-Alain Miller, trans. John Forrester (New York/ London: Norton, 1991).

LEAR, Jonathan, Happiness, Death, and the Remainder of Life (Cambridge, MA: Harvard University Press, 2000).

LUXEMBURG, Rosa, “Die Ordnung herrscht in Berlin”, in: Die Rote Fahne, Nr. 14 (14. Januar 1919), stable URL: https://www.marxists.org/deutsch/archiv/luxemburg/1919/01/ordnung.htm. 
LUXEMBURG, Rosa, “Order Prevails in Berlin”, stable URL: https://www.marxists.org/archive/ luxemburg/1919/01/14.htm.

MARX, Karl and ENGELS, Frederick, "Manifesto of the Communist Party", in: Karl Marx, Frederick Engels, Collected Works, 6: Marx and Engels 1845-48 (London/New York/Moscow: Lawrence \& Wishart, International Publishers/Progress Publishers, 1976).

MARX, Karl, “A Contribution to the Critique of Political Economy”, in: Karl Marx, Frederick Engels, Collected Works, 29: Karl Marx 1857-61 (London/New York/Moscow: Lawrence \& Wishart, International Publishers/Progress Publishers, 1987).

MARX, Karl, “Speech at anniversary of the People's Paper", first published in: The People's Paper (April 19, 1856), stable URL: https://www.marxists.org/archive/marx/works/1856/04/14.htm.

Marx, Karl, “The Poverty of Philosophy”, in: Karl Marx, Frederick Engels, Collected Works, 6: Marx and Engels 1845-48 (London/New York/Moscow: Lawrence \& Wishart, International Publishers/ Progress Publishers, 1976).

MARX, Karl, Contribution to the Critique of Hegel's Philosophy of Right, stable URL: https:// www.marxists.org/archive/marx/works/1843/critique-hpr/intro.htm.

MARX, Karl, "Der achtzehnte Brumaire des Louis Bonaparte”, in: Marx-Engels-Werke, vol. 8, ed. Institut für Marxismus-Leninismus beim ZK der SED (Berlin: Dietz, 1975).

MARX, Karl, The Eighteenth Brumaire of Louis Bonaparte (New York: International Publishers, 1963).

ŽIŽEK, Slavoj, The Fragile Absolute - or, Why is the Christian Legacy Worth Fighting for (London/ New York: Verso, 2000).

ŽIŽEK, Slavoj, The Ticklish Subject: The Absent Centre of Political Ontology (London: Verso, 1999). ZUPANČIČ, Alenka, The Odd One In. On Comedy (Cambridge, MA/London: MIT Press, 2008).

\section{ENDNOTES}

1. Rebecca Comay, Mourning Sickness: Hegel and the French Revolution (Stanford: Stanford University Press, 2011), p. 62.

2. Friedrich Engels, "Socialism: Utopian and Scientific", 1892 English Edition Introduction, stable URL: https://www.marxists.org/archive/marx/works/1880/soc-utop/int-hist.htm.

This paper is a work in progress. Parts of section III and IV have been published in an earlier article under the title "The Messianic Without Messianism. Walter Benjamin's Materialist Theology", in: Anthropology \& Materialism. A Journal of Social Research, No. 1 (2013). Earlier versions have been presented in June 2015 at "The Tradition of the Oppressed" workshop at the Multimedia Institute klub MaMa Zagreb, in July 2015, at the "Memorial For(u)ms - Histories of Possibility" symposium at Hebbel am Ufer Theatre Berlin, in March 2016, at the "History as Tragedy, Comedy and Farce" workshop at the American University of Beirut, and in April 2016 at the American University in Cairo. I would like to thank Haytham El-Wardany, Jana Tsoneva, Tihana Pupovac, Emin Eminagic, Petar Milat, Rachel Aumiller, Gal Kirn, Boris Buden, Jodi Dean, Gerald Raunig, Antonia Majaca, Hakem Al-Rustom, Aaron Schuster, Jan Sieber, and Sebastian Truskolaski for their remarks and comments during these events and the editing process.

3. Karl Marx, "The Poverty of Philosophy", in: Karl Marx, Friedrich Engels, Collected Works, 6: Marx and Engels 1845-48 (London/New York/Moscow: Lawrence \& Wishart, International Publishers/ Progress Publishers, 1976), p. 175.

4. Ibid. 
5. Karl Marx and Friedrich Engels, "Manifesto of the Communist Party", in: Karl Marx, Friedrich Engels, Collected Works, 6: Marx and Engels 1845-48 (London/New York/Moscow: Lawrence \& Wishart, International Publishers/Progress Publishers, 1976), p. 487.

6. Ibid.

7. Ibid, p. 504.

8. References to the works of Walter Benjamin are abbreviated as follows: AP: Walter Benjamin, The Arcades Project, trans. Howard Eiland \& Kevin McLaughlin (Cambridge, MA: Belknap Press of Harvard University Press, 1999); GS: Walter Benjamin, Gesammelte Schriften, eds. Hermann Schweppenhäuser \& Rolf Tiedemann, 7 vols. (Frankfurt/Main: Suhrkamp, 1972ff.); SW: Walter Benjamin, Selected Writings, eds. Marcus Bullock \& Michael W. Jennings, 4 vols. (Cambridge, MA: Belknap Press of Harvard Univ. Press, 1996ff.).

9. Consider thesis VII "On the Concept of History" (1940): "According to traditional practice, the spoils are carried in the procession. They are called 'cultural treasures', and a historical materialist views them with cautious detachment. For in every case these treasures have a lineage which he cannot contemplate without horror. They owe their existence not only to the efforts of the great geniuses who created them, but also to the anonymous toil of others who lived in the same period. There is no document of culture which is not at the same time a document of barbarism" (Walter Benjamin, "On the Concept of History", in: Selected Writings 4, eds. Howard Eiland \& Michael W. Jennings [Cambridge, MA: Belknap Press of Harvard University Press, 2003], p. 391.)

10. Karl Marx, "A Contribution to the Critique of Political Economy", in: Karl Marx, Friedrich Engels, Collected Works, 29: Karl Marx 1857-61 (London/New York/Moscow: Lawrence \& Wishart, International Publishers/Progress Publishers, 1987), p. 263.

11. Italics mine.

12. English trans. mine, in collaboration with Jacob Bard-Rosenberg, stable URL: http:// anthropologicalmaterialism.hypotheses.org/2128.

13. Trans. changed. Cf. GS I, p. 1245.

14. Karl Marx, "Speech at anniversary of the People's Paper", first published in: "The People's Paper", (1856), stable URL: https://www.marxists.org/archive/marx/works/1856/04/14.htm. Benjamin was familiar with this text and quoted the entire passage in The Arcades Project (AP a $17 a, 4)$.

15. Ibid.

16. Slavoj Žižek, The Fragile Absolute - or, Why is the Christian Legacy Worth Fighting for (London/New York: Verso, 2000), p. 89.

17. Ibid, p. $89 f$.

18. Ibid, p. 90.

19. Slavoj Žižek, The Ticklish Subject. The Absent Centre of Political Ontology (London: Verso, 1999), p. 375.

20. Werner Hamacher, “'Now': Walter Benjamin on Historical Time”, in: Walter Benjamin and History, ed. Andrew Benjamin (London/New York: Continuum, 2005), p. 38.

21. Ibid.

22. Jonathan Lear, Happiness, Death, and the Remainder of Life (Cambridge, MA: Harvard University Press, 2000), p. 129. As Lear notes, in the English language the disruptive meaning of happiness as a "lucky break" can still be detected in the word "happenstance." (Ibid.) And indeed, 'happenstance' is a compound word made of 'happen' and 'circumstance' - a lucky circumstance that unpredictably occurred.

23. Ibid.

24. Hamacher, “'Now': Walter Benjamin on Historical Time”, p. 150.

25. Jacques Lacan, The Seminar of Jacques Lacan, Book 1: Freud's Papers on Technique 1953-1954, ed. Jacques-Alain Miller, trans. John Forrester (New York/London: Norton, 1991), p. 12. 
26. Karl Marx, The Eighteenth Brumaire of Louis Bonaparte (New York: International Publishers, 1963), p. 15; Cf. Marx: "Die Menschen machen ihre eigene Geschichte, aber sie machen sie nicht aus freien Stücken, nicht unter selbstgewählten, sondern unter unmittelbar vorgefundenen, gegebenen und überlieferten Umständen. Die Tradition aller toten Geschlechter lastet wie ein Alp auf dem Gehirne der Lebenden" (Karl Marx, "Der achtzehnte Brumaire des Louis Bonaparte", in: Marx-Engels-Werke, vol. 8, ed. Institut für Marxismus-Leninismus beim ZK der SED [Berlin: Dietz, 1975], p. 115.)

27. Jaques Derrida, Specters of Marx. The State of the Debt, the Work of Mourning and the New International, trans. Peggy Kamuf (London/New York: Routledge, 1994).

28. The original passage appears in: Karl Marx, Contribution to the Critique of Hegel's Philosophy of Right [Zur Kritik der Hegelschen Rechtsphilosophie], stable URL: https://www.marxists.org/archive/ marx/works/1843/critique-hpr/intro.htm.

29. Ibid.

30. Ibid.

31. Marx, Eighteenth Brumaire, p. 18.

32. Alenka Zupančič, The Odd One In. On Comedy (Cambridge, MA/London: MIT Press, 2008), p. 149.

33. Marx, Karl, Eighteenth Brumaire, p. 15.

34. Ibid.

35. Ibid.

36. Ibid, p. 17.

37. Cf. GS VII, p. 474.

38. Cf. Benjamin's remarks on Brecht's epic theatre: “Einen Text zitieren, schließt ein: seinen Zusammenhang unterbrechen. Es ist daher wohl verständlich, daß das epische Theater, das auf die Unterbrechung gestellt ist, ein in spezifischem Sinne zitierbares ist" (GS II, p. 536).

39. Marx, Eighteenth Brumaire, p. 19.

40. Zupančič, The Odd One In, p. 153.

41. In another thesis "On the Concept of History" Benjamin defines this memory with reference to a Proustian mémoire involontaire, the content of which he describes as the "dialectical image": "Articulating the past historically means recognizing those elements of the past which come together in the constellation of a single moment. Historical cognition is possible only within the historical moment. But cognition within the historical moment is always cognition of a moment. In drawing itself together in the moment - in the dialectical image - the past becomes part of humanity's involuntary memory" (SW 4, p. 403, trans. changed).

42. A more detailed explication of this intricate logic can be found in section III of my article "Walter Benjamin and the Subject of Historical Cognition", in: Walter Benjamin Unbound, Special Issue of Annals of Scholarship, eds. Alexander Gelley, Ilka Kressner, Michael G. Levine, vol. 21.1 (2015), pp. 23-42.

43. Translation mine, in collaboration with Urška Brodar.

44. For more information see the catalogue of the Memorial For $(u) m s$ - Histories of Possibility symposium, curated by Antonia Majaca at Hebbel am Ufer Theatre, Berlin, July 3-4, 2014, as part of the project Monument to Revolution by Sanja Ivekovic, 'Ich war, ich bin, ich werde sein!', June 6 August 1, 2015, DAAD Gallery, Berlin.

45. This inscription was also added to the completed monument, see http:// www.sozialistenfriedhof.de/revolutionsdenkmal.html, http://thecharnelhouse.org/2013/07/10/ mies-memorial-to-rosa-luxemburg-and-karl-liebknecht-1926 and http://www.moma.org/ collection/object.php?object_id=87517.

46. Ferdinand Freiligrath, "Die Revolution", in: Neuere politische und soziale Gedichte, 1849-51, stable URL: http://gutenberg.spiegel.de/buch/ferdinand-freiligrath-gedichte-5009/30.

47. Rosa Luxemburg, "Order Prevails in Berlin", stable URL: https://www.marxists.org/archive/ luxemburg/1919/01/14.htm; Cf. the German original text: “'Ordnung herrscht in Berlin!' Ihr 
stumpfen Schergen! Eure 'Ordnung' ist auf Sand gebaut. Die Revolution wird sich morgen schon 'rasselnd wieder in die Höh' richten' und zu eurem Schrecken mit Posaunenklang verkünden: Ich war, ich bin, ich werde sein!" (Rosa Luxemburg, "Die Ordnung herrscht in Berlin", in: Die Rote Fahne, No. 14 (14. Januar 1919), stable URL: https://www.marxists.org/deutsch/archiv/ luxemburg/1919/01/ordnung.htm).

48. "Wo Es war, soll Ich werden. Es ist Kulturarbeit etwa wie die Trockenlegung der Zuydersee" (Sigmund Freud, "Neue Folge der Vorlesungen zur Einführung in die Psychoanalyse", in: Gesammelte Werke, vol. 15 [London: Imago, 1940; Frankfurt/Main: Fischer, 1961], p. 86.)

49. Cf. the last lines of Hegel's Phänomenologie des Geistes: "Das Ziel, das absolute Wissen, oder der sich als Geist wissende Geist hat zu seinem Wege die Erinnerung der Geister, wie sie an ihnen selbst sind und die Organisation ihres Reichs vollbringen. Ihre Aufbewahrung nach der Seite ihres freien, in der Form der Zufälligkeit erscheinenden Daseins ist die Geschichte, nach der Seite ihrer begriffenen Organisation aber die Wissenschaft des erscheinenden Wissens; beide zusammen, die begriffene Geschichte, bilden die Erinnerung und die Schädelstätte des absoluten Geistes, die Wirklichkeit, Wahrheit und Gewißheit seines Throns, ohne den er das leblose Einsame wäre; nur - aus dem Kelche dieses Geisterreiches/schäumt ihm seine Unendlichkeit.” (Georg W. F. Hegel, “ Phänomenologie des Geistes”, in: Werke, vol. 3, eds. Eva Moldenhauer \& Karl Markus Michel [Frankfurt/ Main: Suhrkamp, 1986], p. 591.)

50. Nonetheless, Benjamin's term for negativity is not Hegelian; what I have called elsewhere Benjamin's 'messianic nihilism' has a different philosophical and theological genealogy. However, in principle the translatability of Benjamin's unstable ('weak') messianic agency of deforming, depositing, dismantling, and Hegel's work of the negative is not to be ruled out. A more detailed discussion can be found in my articles "A Non-Nullified Nothingness: Walter Benjamin and the Messianic", in: Stasis. Journal in Social and Political Theory, "Politics of Negativity", No. 1 (Fall 2013), pp. 82-108, and in section II of "The Messianic Without Messianism. Walter Benjamin's Materialist Theology”, in: Anthropology \& Materialism. A Journal of Social Research , No. 1 (2013), and "Politics of 'Pure Means': Walter Benjamin on Divine Violence”, in: Black Box: A Record of the Catastrophe, vol. 1 (Dec. 2015), pp. 97-103, sections 7 and 8.

51. English trans. mine, in collaboration with Jacob Bard-Rosenberg, stable URL http:// anthropologicalmaterialism.hypotheses.org/2128.

\section{ABSTRACTS}

As the proverb has it, 'tradition is not to preserve the ashes but to pass on the flame'. Taking this image as a starting point, this paper is interested in non-conservative concepts of tradition and (dis)continuity. If the concept of tradition is normally associated with continuity, the concept of tradition poses the question of transmittability. Is there a continuous medium in which narrations, customs, rites or other material practices can be handed down from the past to the present? If the transmittability of tradition is not a given, a commodified object, but subject to historical change, the question of tradition and inheritance is inextricably linked to social and political struggles. The concept of tradition, however, has mostly been theorized by conservative thinkers. In this vein, traditional historical materialism viewed tradition as a counterprogressive retarding force. Walter Benjamin (1940), however, proposed a different concept of historical time and tradition. History is not based on a progressive flow of "homogeneous, empty time" but on disruptive constellations of the present and the past. The past is never fully gone; it can never be fully historicized. The medium in which the present is connected to all lost causes and struggles of those who literally and metaphorically lost their histories is called the "tradition of the oppressed." Paradoxically, this medium is a discontinuum - its texture is woven out of struggles, empty-spots and disconnected elements which cannot be represented in one 
transmittable image or inscribed into one multifaceted yet coherent world-history. If the "tradition of all dead generations weighs like a nightmare on the brains of the living" (Marx), then the tradition of the oppressed will also haunt all attempts to repress it completely and erase its experience in the linear continuum of "victor's history." But how are we to pass on an oppressed tradition? How can the tradition of the oppressed be recalled, actualized and "worked through"?

INDEX

Keywords: Benjamin Walter, Marx Karl, Luxemburg Rosa, Freud Sigmund, historiography, philosophy, psychoanalysis

\section{AUTHOR}

\section{SAMI KHATIB}

American University of Beirut 